\title{
Institutional Logics and Community Service-Learning in Higher Education
}

\author{
Alison Taylor \\ University of British Columbia \\ Renate Kahlke \\ University of Alberta
}

\begin{abstract}
This paper explores how community service-learning (CSL) participants negotiate competing institutional logics in Canadian higher education. Drawing theoretically from new institutionalism and work on institutional logics, we consider how CSL has developed in Canadian universities and how participants discuss CSL in relation to other dominant institutional logics in higher education. Our analysis suggests participants' responses to competing community, professional, and market logics vary depending on their positions within the field. We see actors' use of hybrid logics to validate communityengaged learning as the strategy most likely to effect change in the field.
\end{abstract}

\section{Résumé}

Cet article s’intéresse aux façons dont les participants à une démarche d'apprentissage par le service communautaire (ASC) s'accommodent des différents courants institutionnels présents dans les institutions d'enseignement postsecondaire au Canada. À partir des théories du nouvel institutionnalisme et des divers courants de pensée sur l'institutionnalisme, nous retraçons l'évolution du concept d'ASC au sein des universités canadiennes, tout en discutant des façons dont les participants à cetterecherche comparent l'ASC à d'autres approches sur l'institutionnalisme en vigueur en milieu universitaire. Selon notre analyse, les réactions des participants aux approches communautaires, professionnelles et commerciales des institutions concurrentes varient selon les rôles et postes qu'ils occupent dans le milieu universitaire. Les participants adoptent une approche hybride pour valider l'ASC comme étant une stratégie porteuse de changements. 


\section{Introduction}

Community service-learning (CSL) programs have been a common feature in US higher education (HE) for decades and have proliferated in Canadian universities since the early 1990s. Reflecting their quest for legitimacy, the topic of "institutionalizing" service learning within $\mathrm{HE}$ is a key theme in the US literature (e.g., Bringle \& Hatcher, 200o; Furco, 2002). However, our empirical study of Canadian CSL participants suggests that the institutionalization aspiration is complicated because of tensions within HE. This paper looks at how actors engaging with CSL in Canada respond to these tensions, which reflect competing institutional logics in the HE field. Our analysis suggests participants' responses to competing community, professional, and market logics vary depending on their positions within the field. We see actors' use of hybrid logics to validate communityengaged learning as the strategy most likely to effect change in the field.

\section{Literature Review}

CSL integrates student placements or projects in the community with intentional learning activities in university classrooms. Although community-based learning is not new, the establishment of CSL units in Canadian HE institutions is a recent trend. The extensive literature on service learning in the United States reflects its longer history there (Taylor et al., 2015). ${ }^{1}$ Lounsbury and Pollack (2001) discussed the involvement of the US federal government in service learning in the 1970s through program funding allocated to promote student engagement in community-based anti-poverty work. The authors traced a shift in policy, beginning in the 1980s, toward constructing service learning as pedagogy and suggested that such a shift served to maintain legitimacy in a more conservative climate. Part of legitimizing service learning (and community engagement more broadly) involves advocating for its institutionalization within HE (Bringle \& Hatcher, 2000; Furco, 2002; Holland, 1997; Hudson \& Trudeau, 1995; Sandmann, Saltmarsh, \& O’Meara, 2008).

The process of institutionalizing community engagement occurs when it becomes central to the mission, policies, and day-to-day activities of universities. US authors tend to assume that institutionalizing CSL is desirable (e.g., Bringle \& Hatcher, 2000), challenging (e.g., Hudson \& Trudeau, 1995), involves the transformation of HE (e.g., Sandmann et al., 2008), and proceeds in stages (e.g., Furco, 2002; Holland, 1997). Barriers to the institutionalization of CSL include the failure of policies to reward community engagement, lack of resources, and lack of integration into the academic core of institutions (Bringle \& Hatcher, 2000). Sandmann et al. (2008) added that institutionalizing the scholarship of engagement requires changes that transform institutional culture, because it poses critical epistemological questions about "how knowledge is constructed and what is accepted as legitimate knowledge in the academy" (p. 48). Butin (2010), on the other hand, argued that rather than attempting to change the academy, an academic home should be created for community-university engagement activities such as service learning so that they can gain professional and social legitimacy. Despite such differences, most writers describe institutionalization as an activity that proceeds in stages across $\mathrm{HE}$.

As noted above, some institutional theorists describe stages of institutionalization that are, to some extent, teleological. For example, Tolbert and Zucker (1996) described a process that moves from habitualization (e.g., formalizing behaviours in organizational policies 
and procedures in response to an issue) to objectification, where structures become more widespread, accepted, and independent of specific individuals, to sedimentation, indicated by the continuity of a structure across generations. They suggest that the factors affecting institutionalization include both the number (and status) of champions and the degree to which adoption is associated with costly changes. CSL writers add that institutionalization is evidenced by the extent to which an organization's mission, policies, and structures support involvement in service learning. Some types of HE organizations-for example, those with a religious tradition (Hudson \& Trudeau, 1995) or those having "unique relationships with a community or region" (Holland, 1997, p. 39)-tend to have the highest commitment to service learning and community engagement, presumably because of values congruence. Thus, universities are diverse, and their responses to their environments vary.

While the "stages of institutionalization" approach may be helpful in understanding the development of particular structures over time, it is less helpful in capturing the complexity of individual and organizational responses in contexts where there are competing institutional logics. Institutional logics are defined as the "belief systems and related practices that predominate in an organizational field" (Reay \& Hinings, 2009, p. 629); they provide meaning to and organize daily activity (Thornton, Ocasio, \& Lounsbury, 2012). The institutional logics perspective sees society as an inter-institutional system comprised of multiple and potentially contradictory logics (e.g., market, state, family, religion) (Friedland \& Alford, 1991). These logics vary across time and contexts (Besharov \& Smith, 2014). Competition between logics can lead to strategic mobilization and countermobilization (Stryker, 2000). Thus, rather than engaging with institutionalization as necessarily desirable, we view actors' engagement with CSL as messy and diverse, leading to outcomes that are both problematic and productive.

Reforms toward marketization, more formal mechanisms of control, and instrumental views of knowledge conflict with previous logics in the field of HE (Gumport, 2000; Townley, 1997). In particular, our study considers competition between market, community, and professional logics (Thornton et al., 2012) through interviews with service learning participants. Thornton and colleagues suggested that while the source of legitimacy in community logics involves belief in trust and reciprocity, the source in market logics is share price, and legitimacy in professional logics stems from personal expertise. Legitimacy reflects the social construction of beliefs about how things should be done (Deephouse \& Suchman, 2008). The source of authority in community logics is a commitment to community values, while that in market logics is shareholder activism, and in professional logics, authority comes from the professional association. Finally, while the source of identity in community logics involves emotional connection, identity in professional logics derives from personal reputation, while market logics are described as "faceless" (Thornton et al., 2012, p. 6).

Naturally, these logics are contextual (Thornton et al., 2012) - what counts as "reciprocity" can mean different things to different people; "personal expertise" is likewise constructed because what constitutes an "expert" is grounded in a particular disciplinary context. Logics are not static but are themselves contextual and shifting - there is no single, authentic "community" (Ibàñez-Carrasco \& Riaño-Alcalá, 2009), nor is there a single, authentic community logic. Lee and Lounsbury (2015) have argued that different kinds of community logics not only facilitate different kinds of organizational behaviour but also enable different 
orientations to move toward broader, field-level logics. Community logics can thus "act as a filter for actors in a community to interpret and respond to pressures emanating from wider field-level logics" (Lee \& Lounsbury, 2015, p. 848). Because of this plurality, individuals are able to align themselves with different logics and develop new, hybrid configurations.

We find the general ideas of sources of legitimacy, authority, and identity useful in mapping broad discourses adopted by actors engaging in CSL. According to Lee and Lounsbury (2015), "different societal-level institutional orders (e.g., market, community, state) provide distinct sources of meaning and practice, creating new opportunities to theorize and understand conflict, agency, and change" (p. 847). The interplay between individuals, organizations, and institutions is also an important focus (Thornton \& Ocasio, 2008).

In sum, the community engagement literature, based mostly in the United States, assumes that institutionalizing CSL programs is desirable. Authors focus on the changes in universities that are needed to achieve this aspiration. Given the relative newness of CSL in Canadian HE, as well as reforms that emphasize entrepreneurial behaviour in HE (Barnett, 2011), we argue that the institutionalization aspiration is complicated. We examine how organizational actors respond to the competing institutional logics associated with different environmental pressures.

\section{Methods}

This paper draws on data from a basic interpretive study (Merriam, 2009) investigating how CSL administrators, instructors, and community partners understand their work. Twenty-seven participants in total were recruited from three groups: (i) 17 program leaders or administrators ${ }^{2}$ from nine of the 10 universities that received CSL funding from the J. W. McConnell Family Foundation in 2004, as well as a representative from the foundation; ${ }^{3}$ (ii) six instructors (in three focus groups); and (iii) four community partners at one of the funded universities (in one focus group). Universities that received McConnell funding ${ }^{4}$ were selected because this funding provided an important impetus for the development of service learning in Canadian universities. All interviews or focus groups were conducted between 2012 and 2013 and lasted between one and two hours.

The first author conducted interviews with program leaders as part of a Killam-funded research project that explored the development of programs across Canada. Interviews with instructors and community partners at one of the McConnell-funded universities were part of a related research project exploring the experiences of instructors, community partners, and students. At the time, the first author was a faculty member at this university and was involved in the CSL program, but there was no prior relationship with participants. Statements were made at the beginning of each interview to position the interviewer as a curious researcher and to clarify that there were no "right answers"; interviewers continued to work to ensure that participant voices were valued and social desirability biases in responses were limited as far as possible. Ethical guidelines were followed concerning the voluntary nature of participation, the ability to opt out, and the confidentiality of data.

Our purposeful sampling approach (Merriam, 2009) allowed us to represent a variety of institutional actors and perspectives. Academic and community participants were representative of the larger groups of which they were part; for example, instructors included both tenure-track and sessional instructors, and community participants were from typical partner organizations. Interviews were conducted in the format preferred by partici- 
pants-in small groups or individually. All participants had the option of having their transcripts returned to them, and they could make changes if they wished.

Using the institutional logics perspective (Thornton et al., 2012) as a theoretical lens, interviews were coded using NVivo software. We used an initial coding approach to examine logics employed when participants discussed CSL, followed by focused coding to develop the core categories (Saldaña, 2013) discussed below.

\section{Analysis}

\section{Institutionalizing CSL}

CSL units in this study were located under the Vice-President Academic (teaching), under the Vice-President Research, within a particular faculty, within a specialized unit, or within a Student Affairs portfolio in universities. Units were led variously by tenuretrack academics and by managerial and professional staff. The number of staff and their working conditions also differed (e.g., full-time versus part-time, secure versus contract positions). The questions of location and resources had implications for administrators' views of their work and where they fit in the university. Background also mattered: for example, CSL administrators who had worked previously in the non-profit sector identified primarily as "community people," while others identified more as "university people." Strong ties to a field associated with a particular logic thus reinforced the influence of this logic on members' behaviour (cf. Besharov \& Smith, 2014).

Notably, CSL administrators were aware that program location signified the degree of legitimacy of CSL within the university. One noted, "[N]ow we've got core funding from the university and we're under ... the Academic Vice-President, so it's seen as an academic program" (Interview 1). It was important to be seen as "academic" because of the increased likelihood of dedicated, ongoing resources, including core funding. Another CSL leader was successful in locating the program in a research centre reporting to central administration, which had important implications for the extent to which service learning was seen as legitimate faculty work that was rewarded within the university (cf. Kezar \& Rhoads, 2001). This is consistent with the claim that new organizational forms often align themselves with existing resources and other sources of legitimacy to increase their own legitimacy (Johnson, Dowd, \& Ridgeway, 2006, p. 56). In contrast, a participant whose CSL unit was housed in a student support centre noted challenges in legitimating her work, because it was not perceived as "academic" (Interview 7). Clearly, the location of service learning within universities has implications for how the work is envisioned and legitimated (cf. Kahlke \& Taylor, forthcoming). Further, the entrenched institutional divisions between teaching, research, and service are problematic given that service learning cuts across all three (Kezar \& Rhoads, 2001).

Despite the diversity of forms, isomorphic behaviour-where institutional forms become more similar over time (DiMaggio \& Powell, 1983)-is evident as CSL programs seek legitimacy. The "early adopters" in Canadian universities borrowed from established US programs. One such participant invited leaders from a US institution to help develop a feasibility study for CSL at her Canadian institution. Programs that followed looked to "pioneers" within Canada. The foundation that provided seed funding to the 10 universities also played a key role in disseminating "best practices" within the group and later acted as consultant and resource person to other institutions (Interview 7). 


\section{Institutionalization and Competing Logics}

Interviewed leaders generally felt that CSL had become objectified to the extent that structures have become more widespread and accepted (cf. Tolbert \& Zucker, 1996). For example: "whatever its strengths and weaknesses, [CSL is] well established within the field of universities now. ... So it's not going back, it's in the water supply, if you like" (Interview 7, representative from foundation).

Following the end of foundation funding, all leaders confirmed that their universities had provided some core funding to support CSL units. CSL leaders in large, research-intensive universities in urban centres also noted that it has become part of university strategic plans: "CSL has gone from being a complete unknown entity to being a strategic priority where resources are invested" (Interview 9). In sum, CSL has become partly "institutionalized."

However, community engagement is not a dominant logic within HE; it continues to be an alternative logic (low hybridity) compared to market or professional logics (high hybridity) (cf. Pache \& Santos, 2013). Interview participants suggest that universities legitimate CSL partly because it allows them to claim that they are connecting with community and are also taking steps to engage undergraduate students. For example, leaders referred to the importance of CSL in promoting student engagement: "[CSL] continues as an undergraduate program connected to things like the National Survey on Student Engagement, when that became all the rage at the universities, to pump up their engagement of students" (Interview 3). This echoes the shifting emphasis from service learning as an oppositional program to it becoming, over time, an accepted pedagogical method in the United States (Lounsbury \& Pollack, 2001).

CSL is also seen as attractive to potential donors as universities grapple with declining public funding. For example, a former leader suggested that universities see CSL as a way to bring donations into the university, which may be in tension with the values of staff (Interview 13). She thus acknowledged a potential clash between market and community logics.

Another participant also expressed reservations about the market logic taken up by university administrations:

I went to an event, and the VP of Research, or maybe it was External Relations . .. was like, "Our goal is to be the number one rank with most research dollars in Canada." I'm like, "What kind of a goal is that?" It has nothing to do with anything except money. The goal should be, like, stem cell research or water quality. It's kind of weird. (Interview 9)

Discussion about the trade-offs associated with a focus on "quality versus quantity" in CSL programs also reflected a clash between new public management (cf. Evetts, 2009) and community logic. For example:

[Universities] say [CSL is] about community impact, and even when you're looking at students, they say it's about student learning. But if you ask the VP Administration or VP Finance, it's how many at how low a cost can you put people through [the program]? I've been in rooms when the VP Finance has said, "This is a great program, but you need to do three times as many for exactly the same amount of cost." (Interview 7) 
While emotional connections and relationships are said to be more important within community logic, market logic privileges efficiency (Thornton et al., 2012). A further danger of institutionalizing CSL is that it will become "systematized, routinized, and ... stagnant" (Interview 9). The implication is that as CSL is absorbed into the university, it will lose its capacity to transform HE, "to push the boundaries around what does it mean for a university to be engaging in community" (Interview 9).

Butin's (2010) vision of the institutionalization of service learning challenges this concern. Instead of constructing it as a social movement, as do many US writers, he has advocated for service learning as an intellectual movement that needs to be integrated into the academic structures of universities by becoming "disciplined." Only then will it gain legitimacy, by resonating with academics across fields rather than being scattered "haphazardly and ineffectually" across HE (p. 72). While his argument is compelling, recognizing the different logics at play helps us to better understand reasons for some of the theoretical, pedagogical, and political tensions he has described. Moreover, Butin's approach to institutionalization does not necessarily address the concern about stagnation expressed by the leader quoted above.

The preceding discussion suggests that although CSL appears to have become "embedded," leaders express concerns about its institutionalization within an educational market. In the next section, we argue that although professional and market logics have become dominant within HE, environmental forces in $\mathrm{HE}$ are also pressing universities to consider how elements of community logics might inform their practices (cf. Weiler, 2005). This discussion recognizes that community is not monolithic or all encompassing (Ibàñez-Carrasco \& Riaño-Alcalá, 2009) and that there may be, in fact, more than one community logic at play. At the same time, we propose that community partners (who were exclusively from the non-profit or public sector in the university program examined) exhibited the characteristics associated with community logics by Thornton, Ocasio, and Lounsbury (2012), in particular: a belief in trust and reciprocity, an emphasis on personal investment in the group, and an interest in increasing the status of their work. The discussion that follows examines how actors engaged in CSL at a research-intensive university negotiate conflicting logics by responding to and utilizing various institutional logics as they seek to legitimate their work.

\section{Responses to Competing Institutional Logics}

Stryker (2000) suggested that possible outcomes of struggles over competing institutional logics include the re-institutionalization of a dominant logic, institutional transformation as a new logic replaces an old one, or the creation of a hybrid institutional logic formed by synthesizing elements of multiple logics. In hybrid logics, there is often a persistent tension between synthesized logics, although the intensity of this tension is linked to their compatibility (Thornton et al., 2012). Community, market, and professional logics are most relevant to discussion about CSL in HE.

While struggles between professional and market logics have been occurring for over 25 years, the influence of community logics on HE has increased recently. Bleiklie (2005) commented that, "as society becomes more 'knowledgeable,' higher education comes under pressure to expand the kinds and types of knowledge it provides and to diversify the criteria by which it is judged" (p. 48). Further, there is a growing expectation that univer- 
sities will contribute to the solution of social problems (Weiler, 2005). Therefore, universities face pressure from the institutional environment to respond to community logics.

We expected the discourse of CSL actors to be more aligned with community logics and in tension with both market and professional logics. However, professional, community, and market logics were not separate and distinct in the discourse of study participants. Instead, there was evidence of a hybrid market-professional logic, particularly in relation to knowledge, since the value of the university is increasingly tied to the personal expertise and professional status of academics within a knowledge market. Even individual academics who oppose other elements of market and professional logics in HE tend to legitimate their work in terms of their contributions to markets and their claims to professional expertise.

It was evident that our interview participants were struggling to make market, community, and professional logics cohere. For example, a CSL instructor suggested that the university is interested in becoming "more of a presence globally as a research institution" and is constantly looking at "what new knowledge is being generated and is it knowledge that has a certain kind of cultural currency?" (Instructor, focus group 4). This instructor situated CSL work as contributing in innovative ways to this goal. Rather than attempting to de-legitimate a market-professional logic that constructs a university's success in terms of its global ranking and production of professional knowledge, this actor attempted to create a hybrid institutional logic by advocating for the place of community knowledge within a professional logic (cf. Stryker, 2000). From this perspective, community members are another group of shareholders, seen as having a contribution to make to university knowledge. ${ }^{5}$

Similarly, a tenured faculty member strategically described CSL work as "creative research" as opposed to community-engaged teaching, in acknowledgment of the expectations of a research-intensive university. A third instructor highlighted her CSL teaching on her curriculum vitae because it indicates that she engages in "innovative teaching practices." These examples demonstrate the efforts of some CSL instructors to develop a hybrid logic that synthesizes elements of community and professional logics and is legitimated through existing professional logics and reward structures, specifically tenure and promotion. The claim by entrepreneurial universities that they make knowledge products "perform in the world" (Barnett, 2011, p. 443) may explain such compromises.

Asserting the important role of community organization staff as "co-educators" in CSL is a way of blurring the boundaries between logics. For example, this leader reimagines professional logic by highlighting community partners' expertise:

So now the goal would be that the community actually is elevated to be of equal standing with the faculty.... I'm really focused on the community side, getting the community to the point where they're equal stature to the faculty and really taking on the role of co-education, so that the university is forced to change. (Interview 10)

In one sense, advocating for "equal stature" between faculty and community knowledge is a radical act that challenges the university's claim to ownership of expertise; on another, the statement simply modifies dominant professional logics wherein knowledge/expertise are prioritized over, for example, relationship building. 
Moreover, there is a difference between validating the knowledge of community organization staff and validating the knowledge of the clients and members served by these organizations - the latter would involve a more radical democratization of knowledge. For example, a former CSL leader commented:

[CSL] means that [university] professional expertise goes into the background and [community] citizen expertise to the foreground.... I for one am pretty sceptical about [the community engagement] movement. . . . It's being done for political reasons and because the university's legitimacy is being questioned, so we'll go out there and make like we're doing good things. But it's not getting to ... the hubris of the academic institution. "We're the experts, we have the answers, we have the power, and that's how it should be." (Interview 9)

This participant critiqued universities for strategically employing the logic of community engagement while actual practices conform to dominant market and professional logicsa process referred to by Thornton and colleagues (2012) as strategic decoupling.

Another participant challenged dominant ideas about knowledge and personal expertise within universities when she developed a unique course wherein university students attended classes with inner-city learners in an agency setting. This instructor deliberately set about to de-centre university knowledge:

Discussions of pedagogy were essential because the folks from [the community organization] had that idea that the university is coming, and "they know everything and we don't." We needed to work on that ... the idea that everybody brings their own knowledge to the table. (Instructor, focus group 2)

Her approach initially unsettled university students, who were "frozen and terrified, because they're like, 'Oh my God, how am I going to get an 'A' here?"' While her faculty and department generally supported the initiative, she commented that a lot of people in the university would find her approach "really difficult and kind of appalling in the way that it doesn't necessarily abide by the same rules" as other academic work (Instructor, focus group 2). However, she was able to legitimize her work because of the focus in her disciplinary field on social justice issues and community engagement, suggesting that professional logics are not monolithic but vary within different disciplines and contexts. In addition, she drew on the professional autonomy that comes with being tenured. Therefore, although her goal was to transform the institution, a professional logic allowed her to legitimize her approach.

The preceding examples suggest that although CSL actors were consciously seeking to challenge professional and market logics in HE with community logics, they often relied on, and therefore reified, professional logics to do so. Community partners were more likely to highlight the tension between professional and community logics. For example, a partner remarked:

That's how we do it in the non-profit world. ... You build relationships that mutually constitute one another, are mutually beneficial, and you build on that. ... I think the best professors to be involved are those that are willing to view the community partner as more than just a practical dumping ground for their students. (Community partner, focus group) 
Similarly, another community partner echoed:

[T] he motivation [for engaging in CSL] is simply to develop a symbiotic relationship; obviously it would benefit the agency in the sense that not just for the agency per se but also to provide a ground-level view [for university participants] to a lot of the needs [of clients]. (Community partner, focus group)

Thus, belief in trust, reciprocity, and personal connection was presented as a source of legitimacy.

Another community partner noted that attention to relationships was missing in some of her work with the university:

[In a few CSL classes,] it just seemed like it was an add-on to the course and not anything to invest time in. We use CSL less and less because we just have felt that we put a lot of work into it and it felt like it was a one-way street. . . I don't see us having a role in co-education as much as we could. (Community partner, focus group)

Similarly, a CSL leader (who led a centre that was located in the community) juxtaposed the individualism of professional logic with the commitment to collective values evident in community logic:

[Territorialism in universities] makes me sad because I think what it indicates is that people [i.e., academics] aren't thinking about community. They're thinking about it from their self-interested perspective as opposed to thinking about community as reducing child poverty or making the environment cleaner. When you think about it from that point of view, well, we're all in it together, people. (Interview 4)

These examples suggest that despite attempts to construct hybrid logics, participants saw some elements of community and professional-market logics as contradictory and perhaps irreconcilable but felt forced to make compromises. Some participants also reproduced dominant logics in their discourse. In theory, CSL involves challenging dominant logics in order to change the university; in practice, actors legitimate their activities in ways that are often messy and involve compromise. For example, a sessional instructor was initially very concerned that her CSL course be seen as a "legitimate academic course," that the "syllabus was really rigorous," and that students who chose to participate in a CSL placement were not "getting off lightly." She saw her course as finding legitimacy only through dominant professional logics wherein legitimate knowledge is "academic" or under the purview of the university.

Another instructor, a recent $\mathrm{PhD}$ graduate who was seeking a tenure-track academic appointment, related:

When I was going to do CSL, I was warned against doing it by my former supervisors because they felt it would take me away from my scholarly work and it was a waste of time because it didn't add anything to the scholarly side. ... I've also noticed that the bulk of us who've taught ... CSL in English were sessional. ... I was on a committee a year ago, and I heard about that resistance repeatedly. People 
say, "I don't know why you're doing this, you don't have a lot of time." A lot of it comes down to "this isn't going to further my career." ... The university needs to respect CSL and see it as an important and vital contribution that can ... count towards tenure. (Instructor, focus group)

The tension between seeking status within one's profession (professional logic) versus seeking personal investment in a group (community logic) is evident. Further, the reward structures of universities are rooted in professional logic, highlighting activities that enhance personal expertise and professional standing. The participant above was accurate in noting that sessional instructors, who tend to occupy a precarious and marginal location within universities, are over-represented among CSL instructors. This exacerbates the construction of CSL as a risky professional activity.

From this perspective, Butin's (2010) argument that service learning needs to be transformed into an academic discipline makes sense; it would thereby gain professional legitimacy by controlling its own knowledge production, developing its own disciplinary boundaries and norms, and critiquing and furthering its own practices. Butin's position also suggests that professional logics are not homogenous across the university, and that there is the potential to produce different kinds of professional logics within a new academic discipline.

\section{Concluding Comments}

Our examination of competing institutional logics in HE today and their strategic mobilization by different actors provides a useful way of understanding the place of CSL within the shifting field of Canadian HE. While societal pressures on universities have prompted greater receptivity to community engagement, economic pressures privilege partnerships that are viewed as promising greater returns (e.g., with corporate employers) and devalue university initiatives that are not self-sustaining or revenue generating. Discussions about the stages of institutionalizing CSL fail to capture the complexity of individual and organizational responses in contexts where there are competing institutional logics.

The responses of CSL actors to competing logics partly reflect their strategic assessment of these logics (Stryker, 2000). Participants in this study reproduced dominant logics in their discourse, attempted to replace dominant market and professional logics with community logic, and created hybrid professional-community and market-community logics with elements from each. Responses depended, in part, on an individual's social network and organizational position (Besharov \& Smith, 2014). For example, attempting to develop hybrid logics was the most common response of tenured faculty, while sessional CSL instructors were more likely to reproduce dominant logics. While sessional instructors did not necessarily agree with market and professional logics, those who aspired to more secure academic positions ignored them at their peril. Tenured faculty were more able to reimagine elements of professional logics. CSL leaders also legitimized their work in terms of social pressures for more results-oriented knowledge.

Leaders and instructors also sought to replace dominant university logics with community logics when these logics were seen as incompatible. Community partners were most likely to see market, professional, and community logics as contradictory-and, not surprisingly, to privilege community logics. While a common response was to withdraw 
from CSL activities, one participant suggested that a more strategic mobilization of community counter-logic might be achieved by community organizations becoming more assertive with universities:

Community organizations are complicit in what I would see as some of their weaknesses, but I think, to be fair, they're conditioned to the co-dependency with universities ... since they're not really the powerful partner in the relationship-although they often underestimate what the real power is. They actually do have a lot of power, and they could say "no," and that would bring universities around quite quickly... . So, they can push back if they can organize. (Interview 7, representative from foundation)

University actors were more likely to draw on hybrid market-professional-community logics in legitimizing their work (Stryker, 2000). In one example, leaders and instructors sought to promote the idea that community organizations are important shareholders with a claim on the knowledge of universities. In another example, instructors advocated for CSL, arguing that it enhances the personal and professional status of academics within a knowledge market, reflecting hybrid community-market logic. Similarly, the ideas that community members are also professionals who can add value to university knowledge as co-educators, and that CSL can be legitimated in terms of innovative teaching and research, reflect hybrid community-professional logic. As Thornton and colleagues (2012) suggested: "institutional orders that are more complementary to one another ... have greater transposition capacity amongst their elemental categories than those institutional orders that are in diametric conflict” (p. 125). Thus, the growing requirement for external justification of the university's work (and challenge to professional logic) may at the same time open up space for individuals to advocate for community logic and to challenge dominant logics by employing hybrid logics.

The different strategies adopted by various CSL actors in this study therefore reflected their positions within the institutional field. While some participants reproduced dominant logics to enhance their positions in the university, others used hybrid logics to challenge the status quo, either seeking to replace dominant logics with community logics or blending logics in order to create institutional space more receptive to their unique CSL goals and activities. The "hybridizers" in our study fit the description of this group as "passionate and complex individuals who strongly adhere to several logics and create new institutional arrangements as a means to adapt the world to their cultures and identities" (Pache \& Santos, 2013, p. 27). As noted above, one area of strategic mobilization that appears to be underdeveloped concerns the response of community partners to competing logics. Given increasing demands for university accountability, collective mobilization of this group might provide the needed impetus to increase the influence of community logics in universities.

This study has examined how actors situate themselves relative to several field-level institutional logics: community, market, and professional. We have argued that the institutional logics perspective offers a useful tool with which to intervene in conversations around the institutionalization of CSL. Future research using the institutional logics perspective could productively explore variation within field-level logics and examine the particular norms and strategies as well as sources of legitimacy, authority, and identity associated with the different logics used by groups participating in service learning. For 
instance, given the diversity of organizations within the not-for-profit sector, we might expect to see different variations of community logics. We might also expect to see specific community logics vary within a community organization-not-for-profit executives might speak to very different community logics or employ those logics in very different ways than would front-line workers or the marginalized populations that they serve. Some of these logics might be more complementary to dominant professional and market logics in the academy, enhancing potential for hybridity.

In addition, research focused on service learning programs in different universities would offer insights into the context-specific ways in which participants negotiate competing logics. Finally, closer consideration of how the instantiations of multiple logics in organizations change over time would be valuable (cf. Besharov \& Smith, 2014). This study contributes to the conversation about the institutionalization of CSL by acknowledging tensions as well as productive possibilities within and across different logics in higher education today.

\section{References}

Barnett, R. (2011). The coming of the ecological university. Oxford Review of Education, 37(4), 439-455.

Besharov, M., \& Smith, W. (2014). Multiple institutional logics in organizations: Explaining their varied nature and implications. Academy of Management Review, 39(3), 364-381.

Bleiklie, I. (2005). Organizing higher education in a knowledge society. Higher Education, 49, 31-59.

Bringle, R. G., \& Hatcher J. A. (2000). Institutionalization of service learning in higher education. The Journal of Higher Education, 71(3), 273-290.

Butin, D. (2010). Service learning in theory and practice. New York: Palgrave Macmillan.

Campus Compact. (2015). Mission and vision. Retrieved from http://compact.org/ who-we-are/mission-and-vision/

Deephouse, D. L., \& Suchman, M. (2008). Legitimacy in organizational institutionalism. In R. Greenwood, C. Oliver, D. Sahlin, \& R. Suddaby (Eds.), The SAGE handbook of organizational institutionalism (pp. 49-77). Los Angeles, CA: Sage.

DiMaggio, P. J., \& Powell, W. W. (1983). The iron cage revisited: Institutional isomorphism and collective rationality in organizational fields. American Sociological Review, 48, 147-160.

Evetts, J. (2009). New professionalism and new public management: Changes, continuities and consequences. Comparative Sociology, 8, 247-266.

Friedland, R., \& Alford, R. R. (1991). Bringing society back in: Symbols, practices and institutional contradictions. In W. W. Powell \& P. J. DiMaggio (Eds.), The new institutionalism in organizational analysis (pp. 232-265). Chicago, IL: University of Chicago Press. 
Furco, A. (2002). Self-assessment rubric for the institutionalization of service learning in higher education. Berkeley, CA: Campus Compact.

Gumport, P. (2000). Academic restructuring: Organizational change and institutional imperatives. Higher Education, 39, 67-91.

Holland, B. (1997). Analyzing institutional commitment to service. Michigan Journal of Community Service Learning, 4(1), 30-41.

Hudson, W., \& Trudeau, R. (1995). An essay on the institutionalization of service learning: The genesis of the Feinstein Institute for Public Service. The Michigan Journal of Community Service Learning, 2(1), 150-158.

Ibàñez-Carrasco, F., \& Riaño-Alcalá, P. (2009). Organizing community-based research knowledge between universities and communities: Lessons learned. Community Development Journal, 46(1), 72-88.

Johnson. C., Dowd. T., \& Ridgeway, C. (2006). Legitimacy as a social process. Annual Review of Sociology, 32, 53-78.

Kahlke, R., \& Taylor, A. (forthcoming). The development of community servicelearning in Canada: One size does not fit all. In S. Buhler \& N. Van Styvendale (Eds.), Community service learning in Canada: Critical conversations. Regina, SK: University of Regina Press.

Kezar, A., \& Rhoads, R. (2001). The dynamic tensions of service learning in higher education. The Journal of Higher Education, 72(2), 148-171.

Lee, M. P., \& Lounsbury, M. (2015). Filtering institutional logics. Organization Science, 26(3), 847-866. doi:10.1287/orsc.2014.0959

Lounsbury, M., \& Pollack, S. (2001). Institutionalising civic engagement: Shifting logics and the cultural repackaging of service learning in US higher education. Organization, 8(2), 319-339.

Merriam, S. B. (2009). Qualitative research: A guide to design and implementation. San Francisco, CA: Jossey-Bass.

Pache, A. C., \& Santos, F. (2013). Embedded in hybrid contexts: How individuals in organizations respond to competing institutional logics. Research in the Sociology of Organizations, 39B, 3-35.

Reay, T., \& Hinings, C. R. (2009). Managing competing institutional logics. Organizational Studies, 30, 629-652.

Saldaña, J. (2013). The coding manual for qualitative researchers (2nd ed.). Thousand Oaks, CA: Sage.

Sandmann, L. R., Saltmarsh, J., \& O’Meara, K. (2008). An integrated model for advancing the scholarship of engagement. Journal of Higher Education Outreach and Engagement, 12(1), 47-64.

Stryker, R. (2000). Legitimacy processes as institutional politics: Implications for theory and research in the sociology of organizations. Research in the Sociology of Organizations, 17, 179-223. 
Taylor, A., Butterwick, S., Raykov, M., Glick, S., Peikazadki, N., \& Mehrabi, S. (2015, October). Community service learning in Canadian higher education. Report produced for SSHRC knowledge synthesis grant, Ottawa, ON.

Thornton, P. H., \& Ocasio, W. (2008). Institutional logics. In R. Greenwood, C. Oliver, R. Suddaby, \& K. Sahlin-Andersson (Eds.), Handbook of organizational institutionalism (pp. 100-129). London, UK: Sage.

Thornton, P. H., Ocasio, W., \& Lounsbury, M. (2012). The institutional logics perspective: Foundations, research, and theoretical elaboration. New York, NY: Oxford University Press. doi:10.1093/acprof:oso/9780199601936.001.0001

Tolbert, P. S., \& Zucker, L. G. (1996). The institutionalization of institutional theory. In S. R. Clegg, C. Hardy, \& W. R. Nord (Eds.), Handbook of organization studies (pp. 175-190). Thousand Oaks, CA: Sage.

Townley, B. (1997). The institutional logic of performance appraisal. Organization Studies, 18(2), 261-285.

Weiler, H. (2005). Ambivalence and the politics of knowledge: The struggle for change in German higher education. Higher Education, 49, 177-195.

\section{Notes}

1. Service learning is more institutionalized in the United States. For example, Campus Compact is a national coalition of more than 1,100 college and university presidents that aims "to make civic and community engagement an institutional priority" in higher education (Campus Compact, 2015). Similarly, the Carnegie Foundation provides an elective classification for higher education institutions to be recognized as community-engaged institutions.

2. We have used the term "administrators" throughout this document to refer to faculty members as well as academic and non-academic staff administering CSL units. Clarification of particular roles, where required, is provided in context.

3. The nine included those who consented to participate. Participants from this group included academic directors, recent former directors, program managers, and program coordinators.

4. Neither of the researchers was affiliated with the McConnell Family Foundation.

5. Weiler (2005) commented that the notion of the academy as the place where knowledge is pursued for its own sake is being challenged by the construction of scholars as public servants.

\section{Acknowledgements}

This research was supported by an Insight Grant from the Social Sciences and Humanities Research Council of Canada, as well as a Killam Cornerstone Grant from the University of Alberta. We are grateful to research assistant Zane Hamm for her help with data collection. 


\section{Contact Information}

Alison Taylor

Faculty of Education

University of British Columbia

alison.taylor@ubc.ca

Alison Taylor is a professor in the Educational Studies Department at the University of British Columbia. She is the author of several publications about school-to-work transitions and youth apprenticeship, including Vocational Education in Canada (2016, Oxford University Press). Her current research focuses on community service-learning in higher education contexts.

Renate Kahlke is a postdoctoral fellow in the University of British Columbia's Centre for Health Education Scholarship and a sessional lecturer in the University of Alberta's Department of Educational Policy Studies. Renate has completed a BA Hon in English and an MA in Postcolonial Studies, and she successfully defended a PhD in Educational Policy Studies in 2015. Her dissertation explored how educators in the health professions understand critical thinking, and the values on which those understandings are based. Current research interests include: the values and beliefs informing health professions education, health professional advocacy, and the role of community service learning as pedagogy. 